\title{
Calibration and validation of the AquaCrop model for the soybean crop grown under different levels of irrigation in the Motopiba region, Brazil
}

\author{
Vicente de Paulo Rodrigues da Silva ${ }^{*}$ Roberta Araújo e Silva ${ }^{2}$ Girlene Figueiredo Maciel $^{2}$ \\ Célia Campos Braga ${ }^{1}$ José Luiz Cabral da Silva Júnior ${ }^{4}$ Enio Pereira de Souza ${ }^{1}$ \\ Rafaela Silveira Rodrigues Almeida ${ }^{1}$ Madson Tavares Silva ${ }^{1}$ Romildo Morant de Holanda ${ }^{3}$
}

${ }^{1}$ Universidade Federal de Campina Grande, Av. Aprígio Veloso, 882, Bodocongó, 58109 970, Campina Grande, PB, Brasil. E-mail: vicente@dca.ufcg.edu.br. "Corresponding author.

${ }^{2}$ Universidade Federal de Tocantins, Palmas, TO, Brasil.

${ }^{3}$ Universidade Federal de Pernambuco (UFPE), Recife, PE, Brasil.

${ }^{4}$ Universidade Estadual do Tocantins, Palmas, TO, Brasil.

ABSTRACT: The water-driven AquaCrop model to simulate yield response has been calibrated and validated for soybean cultivated under different water levels irrigation in Matopiba region, Brazil. The crop was submitted to seven irrigation treatments during the dry season and a dry treatment in the rainy season. The model was parameterized and calibrated by using soybean yield data collected at field level. Model performance was evaluated by using the following statistical parameters: prediction error (Pe), Nash-Sutcliffe efficiency index (E), coefficient of determination $\left(R^{2}\right)$, mean absolute error (MAE), root mean square error normalized (RMSEN) and Willmott's index (d). The statistical analyses of the AquaCrop model calibrated for the Matopiba region disclosed error acceptable for yield prediction of soybean grown under tropical climate conditions. Results also indicated that the C2 soybean cultivar is more resistant to water stress than the C1 soybean grown in the Matopiba region, Brazil. In the treatments when the crop was well supplied with water, at least in one phase, the yield was greater than those with drought stress at last in one phase.

Key words: biomass production, evapotranspiration; leaf area index, deficit irrigation; yield.

Calibração e validação do modelo AquaCrop para a cultura de soja cultivada mediante diferentes níveis de irrigação na região de Matopiba, Brasil

RESUMO: O modelo AquaCrop foi calibrado e validado para simular a produtividade da soja cultivada sob diferentes lâminas de irrigação na região de Matopiba, Brasil. A cultura foi submetida a sete tratamentos de irrigação durante a estação seca e um tratamento de sequeiro na estação chuvosa. O modelo foi parametrizado e calibrado utilizando dados de produtividade de soja coletados diretamente em campo. $O$ desempenho do modelo foi avaliado utilizando os seguintes parâmetros estatísticos: erro de predição (Pe), índice de eficiência de NashSutcliffe $(E)$, coeficiente de determinação $\left(R^{2}\right)$, erro médio absoluto (EMA), raiz quadrática do erro médio normalizado (EQEMN) e índice de Willmott (d). As análises estatísticas do modelo AquaCrop calibrado para a região de Matopiba apresentaram erros aceitáveis na predição da produtividade de soja cultivada sob condições climáticas tropicais. Os resultados também indicaram que a cultivar de soja C2 é mais resistente ao estresse hídrico do que a soja Cl cultivada na região de Matopiba, Brasil. Nos tratamentos durante os quais a cultura foi bem abastecida com água, em pelo menos em uma fase, a produtividade foi maior, em vista do estresse hídrico que ocorre em uma fase.

Palavras-chave: produção de biomassa, evapotranspiração, índice de área foliar, déficit de irrigação, produtividade.

\section{INTRODUCTION}

The Matopiba region, which include some areas in the states of Maranhão, Tocantins, Piauí and Bahia, is one of the largest grain producing in Brazil. In agro-meteorological modeling, a number of crop growth models are applied for different purposes, mainly for interpreting experimental results. They simulate crop growing under various environmental and different handling conditions, considering several limiting factors. These models can also reduce the need for long and expensive field experiments (RESOP et al., 2012).

The AquaCrop model (RAES et al., 2009; STEDUTO et al., 2009) was developed by Food and Agriculture Organization (FAO) with a view to predicting yield, water requirements and water productivity under limiting conditions caused by water deficit and irrigation. The advantage of this model is that it requires a minimum of input data 
that can be easily obtained. The AquaCrop model has default values for various parameters of the culture; however, some of these parameters are not universal and; therefore, must be adjusted to local conditions, to cultivars and to different crop management practices. A more detailed description of the model can be reported in RAES et al. (2009), STEDUTO et al. (2009). This model has been used worldwide because it requires a small number of input variables when compared to other models, such as DSSAT, CropSyst, among others.

The AquaCrop accuracy in simulating the yield of different crops has been extensively confirmed in various types of environments by researchers around the world (ARAYA et al., 2010; ZELEKE et al., 2011; STEDUTO et al., 2012). The use of the AquaCrop model is of great importance for agriculture in various parts of the world, where there are major impacts as a result of the growing number of irrigated areas and, consequently, an increase in water consumption. Although, some studies have been focused on soybean, there is still a need to find out the effect of different water level conditions in climate tropical where soybean is intensively grown produce. The AquaCrop model; however, has not yet been tested in major soybean producing countries like Brazil, where the crop is intensively cultivated under irrigation and rainfed system. Therefore, the purpose of the present study is to evaluate the performance of the AquaCrop model for two soybean crop grown at different irrigation water levels and rainfed systems in tropical climate. Next, model results are analyzed to identify which management conditions are more favorable for cultivars growth. Finally, model errors are examined to identify the more resistant cultivar to water stress.

\section{MATERIALS AND METHODS}

The research has been carried out at Matopiba region, Brazil, during two consecutive years. The data were obtained during the dry period (from 20 June, 2014 to 15 October, 2014) and the rainy period (from November 14, 2013 to 16 March, 2015) at the experimental station of the Universidade Federal de Tocantins $\left[10^{\circ} 10\right.$ 'South, $48^{\circ} 21^{\prime}$ ' West and altitude of 216 meters]. Climatic data on the study area collected during the cultivation of soybean in the rainy and dry seasons are shown in figure 1. In the present research, two medium cycles soybean

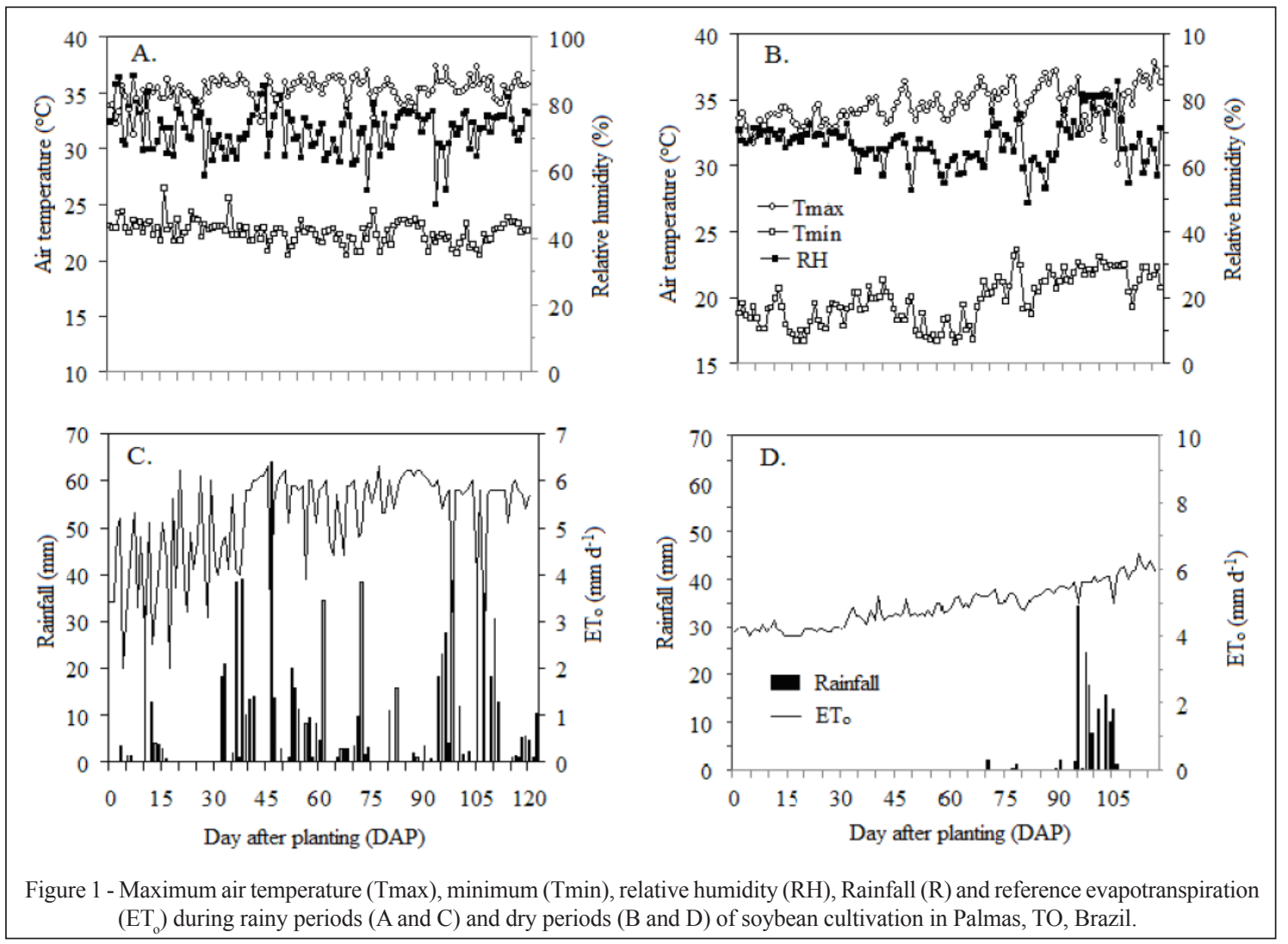

Ciência Rural, v.48, n.1, 2018. 
cultivars (MSOY 9144 - C1 and TMG 1244 - C2) were analyzed. Drip irrigation was used at spaced at every $0.5 \mathrm{~m}$ in both main and lateral lines. Irrigation scheduling was defined by varying the water depth based on crop evapotranspiration (ET), obtained by the equation:

$\mathrm{ET}_{\mathrm{c}}=\mathrm{K}_{\mathrm{c}} \mathrm{ET}_{\mathrm{o}}$

Where $\mathrm{ET}_{0}$ is the reference evapotranspiration $\left(\mathrm{mm} \mathrm{d}^{-1}\right)$, and $\mathrm{K}_{\mathrm{c}}$ represents the coefficient of cultivation for each crop development stage (dimensionless). The $\mathrm{K}_{\mathrm{c}}$ values adopted were $0.4 ; 0.8 ; 1.15 ; 0.8$ and 0.5 for the initial, development, flowering, final stage and harvest, respectively (FAO Irrigation and drainage paper 56). The ET o was calculated by the FAO Penman-Monteith method (ALLEN et al., 1998).

The experimental project was randomized in blocks, with seven treatments and four replications implemented for each cultivar. Despised the boundary line, the useful area of each plot was $3.5 \mathrm{~m}^{2}$, which corresponds to a density of 98 plants. Total amount of water used in each irrigation treatment was defined as follows: $\mathrm{T} 1>\mathrm{T} 2>\mathrm{T} 3>\mathrm{T} 4>\mathrm{T} 5>\mathrm{T} 6>\mathrm{T} 7$. The FAO model AquaCrop (STEDUTO et al., 2009; RAES et al.,
2009) was calibrated and validated for soybean cultivated under different irrigation in Palmas, Tocantins, Brazil. In addition, the software EToCalc (FAO, 2015) was also used which main function is to calculate $\mathrm{ET}_{\mathrm{o}}$ according to FAO standards. Table 1 presents the crop parameters and values resulting from the calibration of the AquaCrop model for soybean growing in Matopiba region.

The structure of the AquaCrop model includes four components: air (with thermal system, rainfall, atmospheric evaporative demand, and carbon dioxide concentration), crop (with growth, development, and production processes), soil (with soil water balance), and management (with irrigation and soil fertility, especially nitrogen, and other aspects related to water). The model works from the biomass calculation which is based on the amount of transpired water. The structural equations model estimate biomass production directly from the crop transpiration via water use efficiency and the final yield based on the harvest index, as follows:

$\mathrm{B}=\mathrm{WP} \times \Sigma^{\mathrm{TR}}$

$\mathrm{Y}=\mathrm{BHI}$

Table 1 - Selected crop parameters and values for calibration of AquaCrop for soybean.

\begin{tabular}{|c|c|c|}
\hline Parameters & C1 (MSOY 9144) & C2 (TMG 1288) \\
\hline Base temperature $\left({ }^{\circ} \mathrm{C}\right)$ & 5.0 & 5.0 \\
\hline Upper temperature $\left({ }^{\circ} \mathrm{C}\right)$ & 30.0 & 30.0 \\
\hline Cover per seedling $\left(\mathrm{cm}^{2}\right.$ plant $\left.{ }^{-1}\right)$ & 5.0 & 5.0 \\
\hline Canopy growth coefficient CGC $\left(\% \mathrm{~d}^{-1}\right)$ & 11.1 & 11.1 \\
\hline Canopy decline coefficient $\mathrm{CDC}\left(\% \mathrm{~d}^{-1)}\right.$ & 3.1 & 3.1 \\
\hline Soil water depletion factor for canopy expansion, upper limit & 0.30 & 0.30 \\
\hline Soil water depletion factor for canopy expansion, lower limit & 0.65 & 0.65 \\
\hline Shape factor for water stress coefficient for canopy expansion & 3.0 & 3.0 \\
\hline Soil water depletion factor for stomatal control & 0.70 & 0.70 \\
\hline Shape factor for water stress coefficient for stomatal control & 3.0 & 3.0 \\
\hline Soil water depletion factor for early canopy senescence & 0.35 & 0.35 \\
\hline Shape factor for water stress coefficient for canopy senescence & 3.0 & 3.0 \\
\hline Normalized water productivity $\mathrm{WP}^{*}\left(\mathrm{~g} \mathrm{~m}^{-2}\right)$ & 15.5 & 15.5 \\
\hline Adjustment for yield formation (\%) & 60 & 71 \\
\hline Normalized water productivity during yield formation $\mathrm{WP}^{*}\left(\mathrm{~g} \mathrm{~m}^{-2}\right)$ & 15.5 & 15.5 \\
\hline Plant density (plants ha ${ }^{-1}$ ) & 286.00 & 286.000 \\
\hline Initial canopy cover CCo (\%) & 1.43 & 1.43 \\
\hline Maximum canopy cover CCx (\%) & 0.99 & 0.99 \\
\hline Time to maximum canopy cover (d) & 65 & 65 \\
\hline Time to flowering (d) & 44 & 44 \\
\hline Length of the flowering stage (d) & 62 & 71 \\
\hline Time to senescence (d) & 102 & 102 \\
\hline Time to maturity (d) & 115 & 115 \\
\hline Maximum rooting depth $(\mathrm{m})$ & 0.60 & 0.60 \\
\hline Minimum effective rooting depth $(\mathrm{m})$ & 0.30 & 0.30 \\
\hline
\end{tabular}

Ciência Rural, v.48, n.1, 2018. 
Where WP is the water productivity ( $\mathrm{kg}$ $\left.\mathrm{m}^{-2} \mathrm{~mm}^{-1}\right), \mathrm{T}$ is the transpiration $(\mathrm{mm}), \mathrm{B}$ represents the dry biomass $(\mathrm{kg}), \mathrm{Y}$ is the final production and HI stands for the harvest index (percentage). Leaf area index (LAI) is the rate of total leaf area by the mean ground area per plant. The canopy cover (CC) was obtained based on LAI following the equation by Hsiao et al (2009):

$\mathrm{CC}=1.005 \times\left[1-\exp (-0.6 \mathrm{LAI}]^{1.2}\right.$

Model validation was based on data obtained from field experiments. Model performance was evaluated using the following statistical parameters: prediction error (Pe), Nash-Sutcliffe efficiency index (E), coefficient of determination $\left(\mathrm{R}^{2}\right)$, mean absolute error (MAE), root mean square error normalized (RMSEN) and Willmott's index (d). Both Pe and d statistics were used to define the robustness of the model as well as to predict the values, while Pe, RMSEN and MAE were used to evaluate the model prediction error.

$$
\begin{gathered}
P e=\frac{\left(\mathrm{S}_{\mathrm{i}}-\mathrm{O}_{\mathrm{i}}\right)}{\mathrm{O}_{\mathrm{i}}} x 100 \\
E=1-\frac{\sum_{i=1}^{N}\left(\mathrm{O}_{\mathrm{i}}-S_{i}\right)^{2}}{\sum_{i-1}^{N}\left(\mathrm{O}_{\mathrm{i}}-\overline{O_{i}}\right)^{2}} \\
\text { RMSEN }=\frac{1}{\overline{\mathrm{O}}} \sqrt{\frac{\sum\left(S_{i}-\mathrm{O}_{\mathrm{i}}\right)^{2}}{\mathrm{~N}}} x 100 \\
M A E=\sqrt{\sum_{i=1}^{N} \frac{\left(S_{i}-O_{i}\right)}{N}}
\end{gathered}
$$

$d=1-\frac{\sum\left(\mathrm{S}_{\mathrm{i}}-\mathrm{O}_{\mathrm{i}}\right)^{2}}{\sum\left(\left|S_{i}-\overline{\mathrm{O}}\right|+\left|\mathrm{O}_{\mathrm{i}}-\overline{\mathrm{O}}\right|\right)^{2}}$

Where $\mathrm{S}_{i}$ and $\mathrm{O}_{i}$ are respectively simulated and observed values. $\overline{\mathrm{O}_{\mathrm{i}}}$ is the average value of $\mathrm{O}_{\mathrm{i}}$ and $\mathrm{N}$ represent the number of observations. When $\mathrm{E}$ and $d$ get closer to the unit, and Pe, RMSEN and MAE approach zero, they represent positive indicators of model performance. The simulation is considered excellent if RMSEN is less than $10 \%$; it is good if it comes between $10 \%$ and $20 \%$; reasonable when it comes between $20 \%$ and $30 \%$; and poor when it is greater than $30 \%$.

\section{RESULTS AND DISCUSSION}

The irrigation treatments were designated as $\mathrm{T} 1, \mathrm{~T} 2, \mathrm{~T} 4, \mathrm{~T} 5, \mathrm{~T} 6$ and $\mathrm{T} 7$, in accordance with the water depth applied as a result of $\mathrm{ET}_{\mathrm{o}}$ and $\mathrm{T} 8$ for rainfed treatment. This last treatment was conducted during the rainy season, which is characterized in this region by abundant rainfall and, consequently, no water deficit. Table 2 shows the water amount applied for $\mathrm{C} 1$ and $\mathrm{C} 2$ cultivars of soybean crop. The T8 treatment was not irrigated, for it was applied during the rainy season in the region, and the total rainfall of this period was $801.4 \mathrm{~mm}$. However, in the dry period, it was $143.6 \mathrm{~mm}$ and; therefore, it did not require any additional irrigation. The differences between the water depth applied by the irrigation treatments were very small; the maximum being $31.8 \mathrm{~mm}$ in the T5 treatment, which correspond to only $7.1 \%$.

\begin{tabular}{|c|c|c|c|}
\hline \multirow[t]{2}{*}{ Treatments } & \multirow[t]{2}{*}{ Depth $(\mathrm{mm})$} & \multicolumn{2}{|c|}{--------------Applied water (mm)------------- } \\
\hline & & C1 (MSOY 9144) & C2 (TMG 1288) \\
\hline $\mathrm{T} 1$ & $25 \% \mathrm{ET}_{\mathrm{o}}$ during $\mathrm{WC}$ & 148.4 & 145.4 \\
\hline $\mathrm{T} 2$ & $100 \% \mathrm{ET}_{\mathrm{o}}$ during $\mathrm{VP}$ and $25 \% \mathrm{ET}_{\mathrm{o}}$ during $\mathrm{RF}$ & 254.3 & 266.1 \\
\hline $\mathrm{T} 3$ & $50 \% \mathrm{ET}_{\mathrm{o}}$ during $\mathrm{TC}$ & 276.0 & 293.3 \\
\hline $\mathrm{T} 4$ & $100 \% \mathrm{ET}_{\mathrm{o}}$ during $\mathrm{VP}$ and $50 \% \mathrm{ET}_{\mathrm{o}}$ during $\mathrm{RF}$ & 368.6 & 373.8 \\
\hline T5 & $25 \% \mathrm{ET}_{\mathrm{o}}$ during $\mathrm{VP}$ and $100 \% \mathrm{ET}_{\mathrm{o}}$ during $\mathrm{RF}$ & 478.8 & 447.0 \\
\hline T6 & $50 \% \mathrm{ET}_{\mathrm{o}}$ during $\mathrm{VP}$ and $100 \% \mathrm{ET}_{\mathrm{o}}$ during $\mathrm{RF}$ & 504.6 & 487.3 \\
\hline $\mathrm{T} 7$ & $100 \% \mathrm{ET}_{\mathrm{o}}$ during $\mathrm{WC}$ & 575.9 & 567.7 \\
\hline T8 & Rainfed & $801.4^{*}$ & $801.4^{*}$ \\
\hline
\end{tabular}
Moreover, an increase in yield with increasing water

Table 2 - Irrigation treatments applied to the soybean crop in relation to the reference evapotranspiration $\left(\mathrm{ET}_{\mathrm{o}}\right)$. WC $=\mathrm{whole}^{\mathrm{c}} \mathrm{crop}$ cycle; $\mathrm{VP}=$ vegetative phase and $\mathrm{RF}=$ reproductive phase.

${ }^{*}$ Total rainfall in the period. 
depth on both cultivars was clearly verified, except in the T7 treatment, which was lower than in the T8. This result suggested that the water stress which occurred in the T6, with the application of only $50 \%$ ET irrigation along the vegetative phase, caused an increase in yield when compared to the $\mathrm{T} 7$ which has not undergone stress, as it was irrigated with $100 \%$ of ET throughout the cycle. There is no appreciable difference between the different irrigation intervals, and the overall low Pe implies that the model could simulate yield for $\mathrm{C} 1$ and $\mathrm{C} 2$ cultivars.

Results of the AquaCrop model simulation for the yield soybean grown in the study area and the model prediction error for each treatment are shown in table 3 . The smaller model prediction errors were reported in the irrigated treatments, while the highest values were obtained in the treatment with no irrigation during the rainy season in both cultivars. These findings may be related to the fact that in cultivation under dry farming conditions, plants can reach, at some points, the water stress condition, thereby limiting their productivity. The high yield crop observed during the rainy period of 5.1 and $4.7 \mathrm{tha}^{-1}$, respectively, for the $\mathrm{C} 1$ and $\mathrm{C} 2$ cultivars are associated to high rainfall and high atmospheric demands along the period (Figure 1C). During this period, the average reference evapotranspiration was $5.2 \mathrm{~mm} \mathrm{~d}^{-1}$, while, in the dry period, it was $4.9 \mathrm{~mm} \mathrm{~d}^{-1}$. Lower yield values were obtained with the T1 treatment for both cultivar C1 $\left(0.7\right.$ ton $\left.\mathrm{ha}^{-1}\right)$ and the cultivar C2 (1.0 ton ha $\left.\mathrm{h}^{-1}\right)$. Paredes et al. (2015) reported yield values for soybean grown in northern China varying from 3.2 to 4.2 ton $\mathrm{ha}^{-1}$. These values are higher than those reported in the present study during the first four irrigation treatments because of the stress level applied to the crop, which was greater than the level obtained in the survey conducted in China.
Cultivar $\mathrm{C} 2$ was more resistant to water stress than cultivar $\mathrm{C} 1$ because in the first four treatments, during which the culture was subjected to stress, C2 yield was greater than that of $\mathrm{C} 1$. Conversely, in the treatments during which the crop was well supplied with water (T5, T6 and T7), or at least in one phase, the culture received a water depth based on $100 \%$ of the $\mathrm{ET}_{\text {o }}$, the $\mathrm{C} 1$ yield was greater than that of $\mathrm{C} 2$. The differences in yield among the same treatments may be attributed to the genetic characteristics of cultivars which responded differently to climatic conditions and to soil moisture throughout the growing period.

High determination coefficient values $\left(\mathrm{r}^{2}\right)$, greater than 0.92 , were obtained by comparing the observed and simulated values of soybean yield (Figure 2). The model overestimated the yield of soybean cultivar $\mathrm{C} 1$ in treatments with low water depth, while for the cultivar C2 an overestimation was observed to occur in treatments with higher irrigation rates. The greatest deviation among the observed and simulated values was reported in the T8 treatment, which corresponds to the rainy season for two cultivars, possibly because the water supply by rainfall was higher than the water demand of crop. XIANGXIANG et al. (2013) observed that wheat yield, as verified by the AquaCrop model, was higher than the one previously observed. They attributed that difference to a larger concentration of rainfall during the harvest season. They also noted that the model had overestimated grain yield in treatments with lower water depth, being underrated with the existence of higher irrigation rates. Figure 3 shows the seasonal course of the water depth of soybean yield of the varieties MSOY 9144 and TMG 1288 grown in Palmas, TO, Brazil.

Statistical evaluation of the AquaCrop model performance on yield prediction of soybean

Table 3 - Observed values (Obs) and simulated values (Sim) on yield (Y) and model prediction error (Pe) of the AquaCrop for each irrigation treatment of C1 soybean cultivars (MSOY 9144) and C2 (TMG 1248) grown in the region of Matopiba, Brazil.

\begin{tabular}{|c|c|c|c|c|c|c|}
\hline \multirow[t]{3}{*}{ Treatment } & \multicolumn{3}{|c|}{ 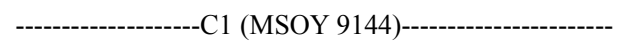 } & \multicolumn{3}{|c|}{--_- } \\
\hline & \multicolumn{3}{|c|}{ 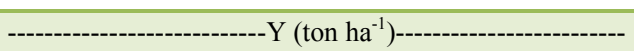 } & \multicolumn{3}{|c|}{ - - } \\
\hline & Obs & Sim & $\mathrm{Pe}(\%)$ & Obs & Sim & $\mathrm{Pe}(\%)$ \\
\hline $\mathrm{T} 1$ & 0.7 & 0.7 & 1.4 & 1.0 & 0.9 & 3.1 \\
\hline $\mathrm{T} 2$ & 1.3 & 1.5 & 10.4 & 1.6 & 1.5 & 1.9 \\
\hline $\mathrm{T} 3$ & 1.4 & 1.5 & 4.2 & 1.9 & 1.9 & 1.1 \\
\hline $\mathrm{T} 4$ & 2.0 & 2.0 & 1.0 & 2.4 & 2.4 & 2.0 \\
\hline T5 & 3.3 & 3.3 & 1.2 & 2.9 & 2.9 & 31.4 \\
\hline T6 & 5.4 & 4.5 & 16.2 & 3.9 & 4.0 & 1.3 \\
\hline $\mathrm{T} 7$ & 4.7 & 4.5 & 4.5 & 3.7 & 3.7 & 0.3 \\
\hline $\mathrm{T} 8$ & 5.1 & 3.8 & 25.7 & 4.7 & 4.1 & 13.4 \\
\hline
\end{tabular}



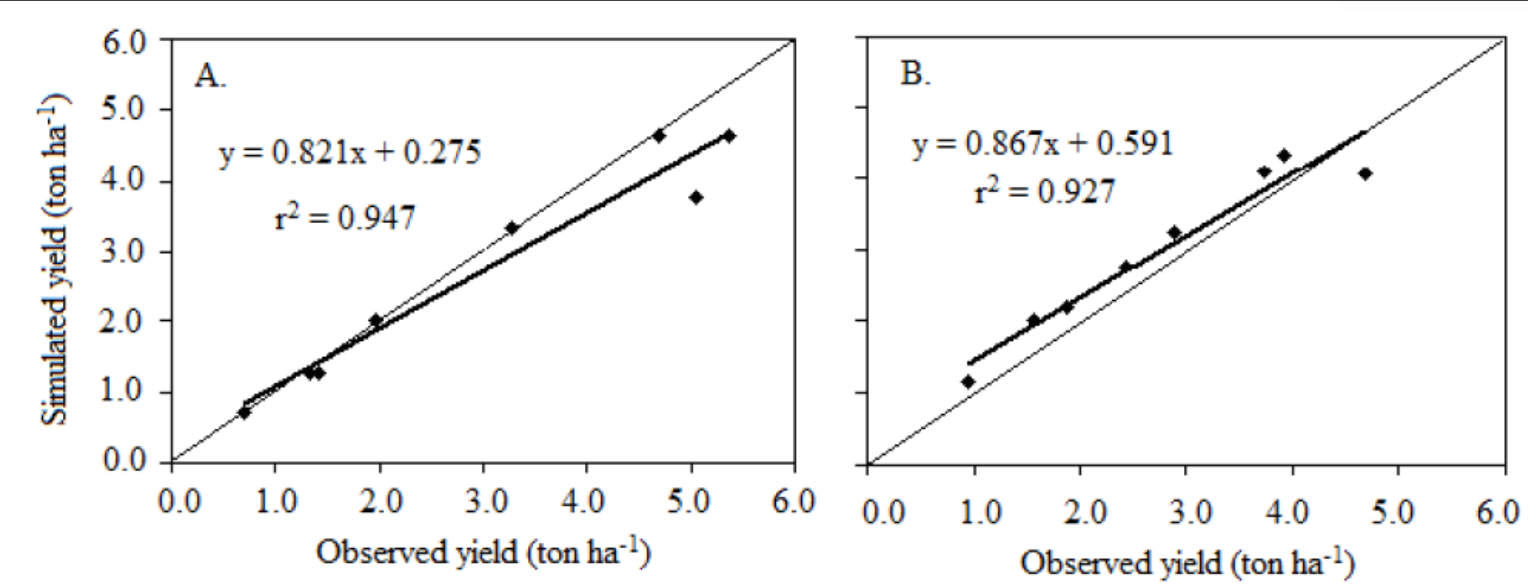

Figure 2 - Comparison between observed and simulated values of soybean yield of the varieties (A) C1 - MSOY 9144 and (B) C2 TMG 1288 grown in Palmas, TO, Brazil.

grown in the Matopiba region, Brazil, for the $\mathrm{C} 1$ and $\mathrm{C} 2$ cultivars is shown in table 4 . The yield values simulated by the model and those measured in the field are similar for both cultivars. However, results showed that the model is far more effective when used under controlled water management conditions than when employed under natural conditions. STRICEVIC et al. (2011), upon analyzing corn yield grown both under rainfed system and irrigated system, noticed that the model performed better under continental conditions than under Mediterranean conditions. Besides, higher productivity variations were observed in extremely wet years.
The AquaCrop model calibrated for simulating the yield of soybean cultivars $\mathrm{C} 2$ and $\mathrm{C} 1$ grown in the Matopiba region under conditions of supplemental irrigation and without irrigation during the rainy season resulted in $0.10<\mathrm{MAE}$ $<0.33$ ton ha $^{-1} ; 8.17<$ RMSEN $<18.8 \% ; 0.89<$ E $<0.96$ and $0.96<\mathrm{d}<0.99$ (Table 3). The simulation was considered excellent for cultivar C2 (RMSEN $<10 \%$ ) and considered good for cultivar C1 (10 $<$ RMSEN $<20$ ) according to the criteria set out above. Thus, one can conclude that the AquaCrop model can be also used for simulating yield of nonperennial crops satisfactorily provided the model is properly parameterized and well calibrated. Similar

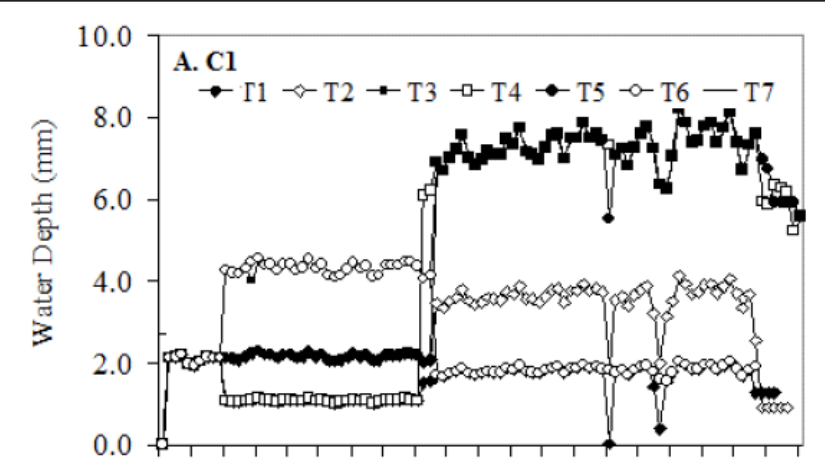

171181191201211221231241251261271

Day after planting

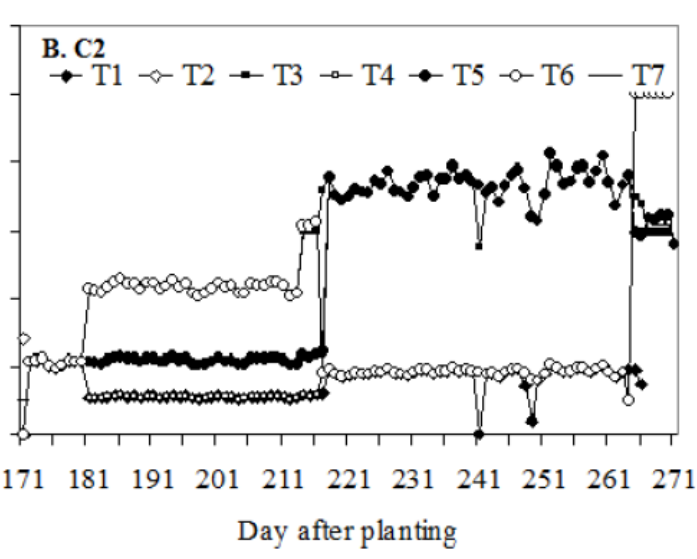

Figure 3 - Seasonal curse of water depth of soybean yield of the varieties (A) C1 - MSOY 9144 and (B) C2 - TMG 1288 grown in Palmas, TO, Brazil. 
Table 4 - AquaCrop model adjustment indicators calibrated for soybean cultivars C1 (MSOY 9144) and C2 (GMT 1248) grown in the Matopiba region, Brazil.

\begin{tabular}{lcccc}
\hline Cultivar & $\begin{array}{c}\text { MAE } \\
(\text { ton ha }\end{array}$ & $\begin{array}{c}\text { RMSEN } \\
(\%)\end{array}$ & E & $\mathrm{d}$ \\
\hline C1 (MSOY 9144) & 0.33 & 18.80 & 0.89 & 0.96 \\
C2 (TMG 1288) & 0.10 & 8.17 & 0.96 & 0.99 \\
\hline
\end{tabular}

$\mathrm{MAE}=$ mean absolute error, $\mathrm{RMSEN}=$ root mean square error normalized, $\mathrm{E}=$ Nash-Sutcliffe efficiency index and $\mathrm{d}=$ Willmott's index.

results were obtained by MIRSAFI et al. (2016) when simulating growth and yield of saffron in Shiraz, Iran by AquaCrop model.

The other statistical indicators have also exhibited optimal fit of the model. However, the best fit was observed to occur in the cultivar $\mathrm{C} 2$ because the statistics indicating the robustness of the model ( $\mathrm{E}$ and $\mathrm{d}$ ) and the model prediction errors (RMSEN and MAE) were less favorable in cultivar C1. PAREDES et al. (2015) used the AquaCrop model to predict soybean yields. They observed the square root average error $(\mathrm{RQEM})=7.3 \%$ and $\mathrm{E}$ ranging from 0.47 to 0.82 . The values of the statistics reported in the present study - conducted in the Matopiba region - are comparable to those obtained in other crops. ABEDINPOUR et al. (2012) reported $0.17<$ MAE $<0.51 \mathrm{t} \mathrm{ha}^{-1}$ and $0.95<\mathrm{E}<0.99$ for corn; IQBAL et al. (2014) found RMSEN $=8.62 \%$ and $d=0.95$ for the wheat grown in North China. The AquaCrop model can be calibrated to simulate soybean yield in Matopiba region and becomes a useful tool to support decision for irrigation scheduling.

\section{CONCLUSION}

The AquaCrop model proved to be more effective when used under controlled water management conditions than when used under natural conditions. The soybean cultivar TMG 1288 is more resistant to water stress than the cultivar MSOY 9144 under the climatic conditions of tropical Brazil. The best fit was observed to occur in the cultivar $\mathrm{C} 2$, because the statistics indicating the robustness of the model (E and D) and the model prediction errors (RMSEN and MAE) were less favorable in cultivar $\mathrm{C} 1$. In the cultivation of soybean in Matopiba region under dry farming conditions, plants can reach, at some points, water stress condition, thereby limiting their productivity.

\section{REFERENCES}

ABEDINPOUR, M. et al. Performance evaluation of AquaCrop model for maize crop in a semi-arid environment. Agricultural Water Management, Amsterdam, v. 110, n. 1, p.55-66, 2012. Available from: <http://www.sciencedirect.com/science/search>. Accessed: Oct. 03, 2016. doi: 10.1016/j.agwat.2012.04.001.

ALLEN, R.G. et al. Crop Evapotranspiration: Guidelines for computing crop water requirements. FAO Irrigation and drainage paper 56. Rome. 300p. 1998. Available from: <http:// academic.uprm.edu/abe/backup $2 /$ tomas $/$ fao\%2056.pdf $>$. Accessed: October 12, 2016.

ARAYA, A. et al. Test of AquaCrop model in simulating biomass and yield of water deficient and irrigated barley (Hordeum vulgare). Agricultural Water Management, Amsterdam, v. 97, p. 1838-1846, 2010. Available from: <http://www.sciencedirect. com/science/search $>$. Accessed: Oct. 16, 2016. doi: 10.1016/j. agwat.2010.06.021

FAO, 2015. ETo calculator. Available from: <http://www.fao.org/ nr/water/eto.html>. Accessed: September 6, 2016.

HSIAO, T.C. et al. AquaCrop-the FAO crop model to simulate yield response to water: III. Parameterization and testing for maize. Agronomy Journal, v.101, n.3, p.448-459, 2009. Available from: $<$ http:/www.sciencedirect.com/science/search $>$. Accessed: Oct. 11, 2016. doi: 10.2134/agronj2008.0218s.

IQBAL, M.A. et al. Evaluation of the FAO AquaCrop model for winter wheat on the North China Plain under deficit irrigation from field experiment to regional yield simulation. Agricultural Water Management, Amsterdam, v. 135, p. 61-72, 2014. Available from: $<$ http://www.sciencedirect.com/science/search $>$. Accessed: Apr. 26, 2016. doi: 10.1016/j.agwat.2013.12.012.

PAREDES, P. et al. Performance assessment of the FAO AquaCrop model for soil water.soil evaporation. biomass and yield of soybeans in North China Plain. Agricultural Water Management, Amsterdam, v. 152, p. 57-71, 2015. Available from: <http://www. sciencedirect.com/science/search $>$. Accessed: Oct. 23, 2016. doi: 10.1016/j.agwat.2014.12.007.

RAES, D. et al. AquaCrop - the FAO crop model to simulate yield response to water. II. Main algorithms and software description. Agronomy Journal, v. 101, p. 438-447, 2009. Available from: $<$ https://dl.sciencesocieties.org/publications/aj/ abstracts $/ 101 / 3 / 438$ ? access $=0 \& v i e w=p d f>$. Accessed: Oct. 08, 2016. doi: 10.2134/agronj2008.0140s.

RESOP, J.P. et al. Combining explanatory crop models with geospatial data for regional analyses of crop yield using field-scale modeling units. Computers and Electronics in Agriculture, v. 89, p. 51-61, 2012. Available from: <http://www.sciencedirect. com/science/search $>$. Accessed: sep. 2216, 2016. doi: 10.1016/j. compag.2012.08.001.

MIRSAFI, Z. S. et al. Assessment of AquaCrop model for simulating growth and yield of saffron (Crocus sativus L.). Scientia Horticulturae, v. 211, p. 343-351. 2016. Available from: <http:// www.sciencedirect.com/science/search>. Accessed: Oct. 26, 2016. doi: 10.1016/j.scienta.2016.09.020.

STEDUTO, P. et al. AquaCrop-The FAO crop model to simulate yield response to water: I. Concepts and underlying principles. 
Agronomy Journal, v. 101, p. 426-437, 2009. Available from: $<\mathrm{http}$ :/www.sciencedirect.com/science/search $>$. Accessed: Oct. 16, 2016. doi: 10.2134/agronj2008.0139s.

STEDUTO, P. et al. AquaCrop: concepts. rationale and operation. In: Crop Yield Response to Water. Irrigation \& Drainage paper vol. 66. FAO. Rome. 2012.

STRICEVIC, S. et al. Assessment of the FAO AquaCrop model in the simulation of rainfed and supplementally irrigated maize. sugar beet and sunflower. Agricultural Water Management,Amsterdam, v. 98, p. 16151621, 2011. Available from: <http://www.sciencedirect.com/science/ search>. Accessed: Oct. 21, 2016. doi: 10.1016/j.agwat.2011.05.011.
ZELEKE, K.T. et al. Calibration and testing of the FAO AquaCrop model for canola. Agronomy Journal, v. 103, p. 1610-1618, 2011. Available from: <http://www.sciencedirect. com/science/search>. Accessed: Oct. 12, 2016. doi: 10.2134/ agronj2011.0150.

XIANGXIANG, W. et al. Evaluation of the AquaCrop model for simulating the impact of water deficits and different irrigation regimes on the biomass and yield of winter wheat grown on China's Loess Plateau. Agricultural Water Management, Amsterdam, v. 29, p. 95-104, 2013. Available from: <http://www.sciencedirect. com/science/search $>$. Accessed: Nov. 11, 2016. doi: 10.1016/j. agwat.2013.07.010. 